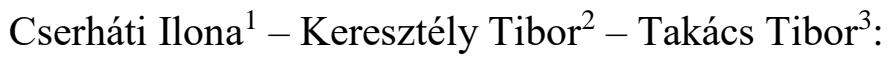

\title{
Versenyképesség és foglalkoztatás az autóiparban \\ Competitiveness and employment in the automotive industry
}

A jármügyártás adja a magyar ipari export egyharmadát, ezért fontos elemezni a COVID-19 terjedése miatt kialakuló keresleti-kínálati sokk szektorhatásait. Egyrészt vizsgáljuk, hogy a globális piacok összeomlása milyen termelési, foglakoztatási hatásokat indukált a szektorban, másrészt az új autók eladási statisztikái alapján nyomon követjük a belföldi kereslet rövid távú reagálását is. Elemezzük a vírussal kapcsolatban meghozott távolságtartási intézkedések hatására felvetődő kérdést: vajon lehetséges-e, hogy még ebben a helyhez kötöttnek tartott szektorban is van helye a rugalmas munkavégzésnek. Becslést készítünk a nemzetgazdasági szintü, valamint a jármügyártásra vonatkozó potenciális távmunka arányra. A modellszámítások alapján a jármügyártásban a munkahelyek 21,7\%-a lenne elvégezhető távolról, rugalmas módon, ami elég magas, bár a becsült nemzetgazdasági átlag, a 28,7\% alatt van.

Since the one third of the Hungarian export comes from the automotive industry, it is important to analyze the impact of COVID-19 crisis on demand and supply in this industry. The paper gives a comprehensive picture of production and employment changes and tries to follow up the respond of domestic demand to the crisis relying on sales statistics. Furthermore, the study examines whether there are opportunities to work from home in this industry and finds that the $21,7 \%$ of the jobs could be done by working from home, which seems high, but is still below the national average $28,7 \%$.

\section{Autóipar koronavírus idején}

Magyarországon az ipar súlya a GDP-ben viszonylag magas: 2019-ben a mutató meghaladta a 24\%-ot: ez a nyolcadik legmagasabb volt az Európai Unióban [KSH, 2020]. Ebben az évben a magyar ipari termelés dinamikája volt a legmagasabb 5,4\%-kal. A régió felzárkózó gazdaságaihoz hasonlóan kiemelt és növekvő súlyú ágazata a jármügyártás, ami 2019-ben a hazai exportértéknek már több mint a harmadát tette ki (1. táblázat). A nagyvállalatok súlya a hazai iparban mind a termelést, mind az exportot tekintve kiemelkedő, az export esetében ez 80\% körül alakult. A jármügyártásban ráadásul a BMW Group új debreceni gyárának létesítésével kapcsolatos előkészítő munkálatok is megkezdődtek.

A koronavírus-válság 2020 második negyedévében jelentős visszaesést okozott a magyar gazdaságban. Az előző év azonos időszakára vetítve a második negyedévi GDP volumene 13,6\%-kal csökkent, ami a már március második felében bevezetett korlátozó intézkedések következménye volt. A feldolgozóipart az átlagnál is súlyosabban érintette a válság, itt a visszaesés mértéke 21,7\% lett. Ebben nyilvánvalóan jelentős szerepet játszott a feldolgozóipar több mint negyedét kitevő jármügyártás alág (CL) zsugorodása. Az alágat

\footnotetext{
1 egyetemi docens Budapest Corvinus Egyetem, Matematikai és Statisztikai Modellezés Intézet, Statisztika Tanszék

2 egyetemi docens Budapest Corvinus Egyetem, Matematikai és Statisztikai Modellezés Intézet, Statisztika Tanszék

${ }^{3}$ egyetemi docens Budapest Corvinus Egyetem, Gazdaság- és Közpolitika Intézet, Gazdaságpolitika és Munkagazdaságtan

Tanszék

A tanulmány a Tématerületi Kiválósági Program támogatásával készült.

DOI: 10.14267/RETP2021.01.04
} 
nagyfokú koncentráltság jellemzi, teljesítménymutatóiban meghatározók a nagy, külföldi tulajdonú autó-, illetve autóalkatrész-gyárak (Audi, Mercedes, Opel, Suzuki). A külgazdasági és külügyminisztertől származó információ szerint 740 autóiparhoz kötődő vállalat müködött a válság kitörésekor, 2020 márciusában. A jármügyártásban foglalkoztatottak száma tíz év alatt megduplázódott: 2019-ben átlagosan meghaladta a 176 ezer főt, ebből a négy nagy autógyár részesedése több mint 21 ezer fö volt. A nagy gyárak hazai beszállítóinak nagy része szintén nemzetközi multik hazai vállalkozásai: a világ top-100 autóipari beszállítóinak mintegy fele jelen van a hazai piacon is. A döntően külpiacra kerülő gépjármüvek exportja is meghatározó: 2019-ben a közúti jármüvek aránya a kivitelben meghaladta a 17,1\%-ot.

1. táblázat: A jármügyártás aránya az ipari termelésben, az export- és a belföldi értékesítésben,

\begin{tabular}{|c|c|c|c|}
\hline \multirow{3}{*}{ Év } & \multicolumn{3}{|c|}{$2001-2019 *$} \\
\cline { 2 - 4 } & $\begin{array}{c}\text { A jármügyártás aránya } \\
\text { termelésben }\end{array}$ & $\begin{array}{c}\text { az ipari } \\
\text { export- } \\
\text { értékesítésben }\end{array}$ & $\begin{array}{c}\text { az ipar belföldi } \\
\text { értékesítésében }\end{array}$ \\
\hline 2001 & $16.4 \%$ & $26.3 \%$ & $2.5 \%$ \\
2002 & $16.0 \%$ & $25.4 \%$ & $2.8 \%$ \\
2003 & $16.9 \%$ & $26.3 \%$ & $3.0 \%$ \\
2004 & $16.3 \%$ & $25.0 \%$ & $2.7 \%$ \\
2005 & $17.1 \%$ & $25.5 \%$ & $3.2 \%$ \\
2006 & $19.0 \%$ & $27.6 \%$ & $3.4 \%$ \\
2007 & $19.8 \%$ & $27.8 \%$ & $3.7 \%$ \\
2008 & $19.3 \%$ & $27.3 \%$ & $3.4 \%$ \\
2009 & $17.1 \%$ & $24.2 \%$ & $2.8 \%$ \\
2010 & $17.6 \%$ & $24.0 \%$ & $2.7 \%$ \\
2011 & $18.1 \%$ & $24.6 \%$ & $2.8 \%$ \\
2012 & $19.2 \%$ & $26.6 \%$ & $2.5 \%$ \\
2013 & $22.9 \%$ & $30.3 \%$ & $3.2 \%$ \\
2014 & $26.0 \%$ & $33.5 \%$ & $4.2 \%$ \\
2015 & $28.4 \%$ & $34.9 \%$ & $5.9 \%$ \\
2016 & $28.8 \%$ & $35.8 \%$ & $6.1 \%$ \\
2017 & $27.5 \%$ & $34.1 \%$ & $6.2 \%$ \\
2018 & $26.7 \%$ & $33.0 \%$ & $6.2 \%$ \\
2019 & $27.7 \%$ & $34.4 \%$ & $7.5 \%$ \\
$*$ * legalább5 föt foglalkoztató vállalatok & KSH STADAT adatbázis alapján \\
& Forrás: saját számítás &
\end{tabular}

Tavasszal szerte Európában szigorú korlátozásokkal reagáltak a járvány kitörésére, a nemzetközi értékláncok müködésében komoly zavarok léptek fel. Márciusban leállt a győri Audi gyár a Volkswagenkonszern német, belga és mexikói telephelyeihez hasonlóan a rendkívüli járványhelyzetre, illetve az alkatrészellátás bizonytalanságaira hivatkozva. A Mercedes és a Suzuki gyárakban a termelés április végéig szünetelt, majd fokozatosan újraindult a termelés, és hasonló volt a helyzet az Opel motorgyár szentgotthárdi gyárában is. Értelemszerủen a hazai beszállítók is kénytelenek voltak leállni. Természetesen nem csak termelői oldalról jelentkezett a válság, a felhasználók is halasztották jármübeszerzéseiket a 
nagyfokú bizonytalanságra való tekintettel. A pánikszerü leállásokat Európában elsősorban a járvánnyal kapcsolatos hiányos ismeretek okozták. Az 1. ábra az új gépjárművek hazai forgalomba helyezését mutatja havi bontásban 2018-2020 között. Ez a mutató is látványosan zuhant 2020 áprilisában és májusában, de júliustól kezdve egy hónap kivételével a számok meghaladták a 2018-as megfelelő adatokat, és megközelítették a 2019-es, egyébként kiugrónak számító értékeket. Megjegyezzük, hogy a használt gépjárművek forgalomba helyezésének mutatója viszont az év végéig elmaradt mind a 2018-as, mind a 2019-es értékektől, de a 2020 decemberi érték az előző évitől már csak 9\% körüli csökkenést jelentett.

A távol-keleti régióban a válság ugyan pár hónappal korábban jelentkezett, az onnan származó információk és megszerzett tapasztalatok nem voltak elegendőek és megbízhatóak ahhoz, hogy Európa elkerülhesse a kényszerü leállásokat. Valójában a kínai jármügyártás márciusban már a kilábalási szakaszban volt, áprilisban a személygépkocsik eladása és termelése már meg is haladta az egy évvel korábbi szintet; az export a májusi mélypont után augusztusban érte el az egy évvel korábbi szintet (lásd a 2. ábrát). (A kereskedelmi célú járművek termelése, eladása és exportja teljesen hasonló módon alakult.)

1. ábra: Új gépjármü forgalomba helyezések havonta, 2018-2020

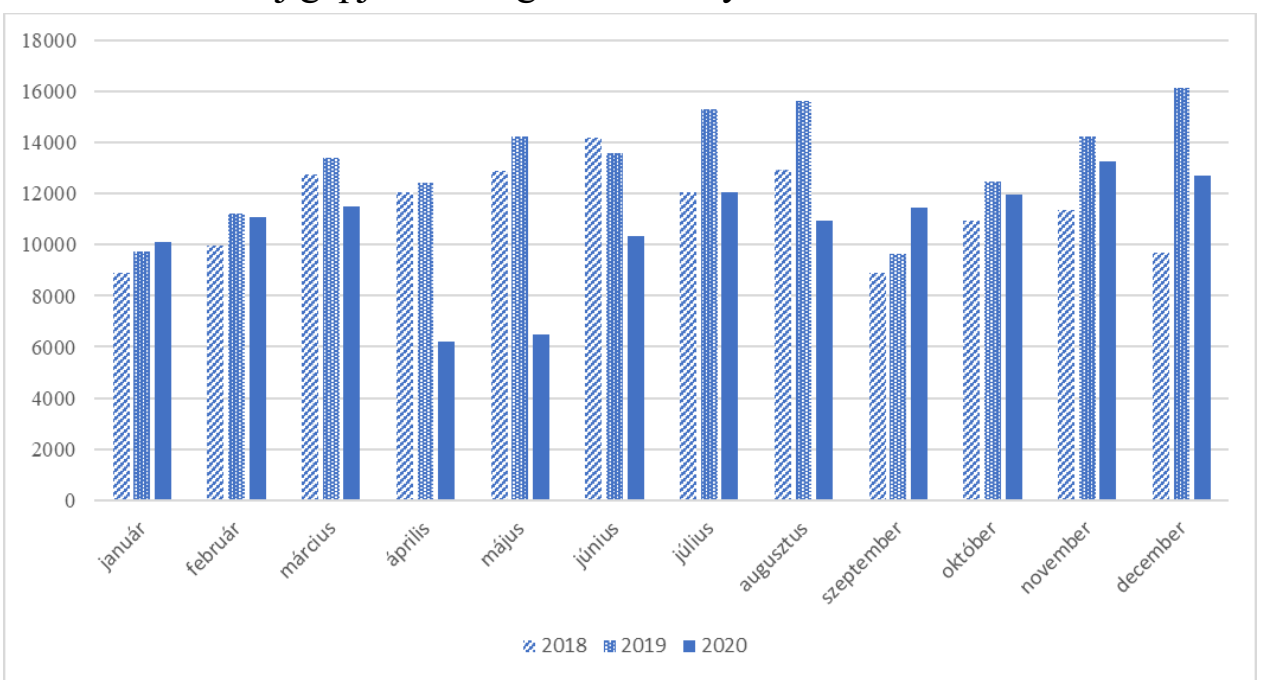

Forrás: Datahouse Kft.

2. ábra: Személygépkocsik termelése, eladása és exportja Kínában (év/év index, százalék)

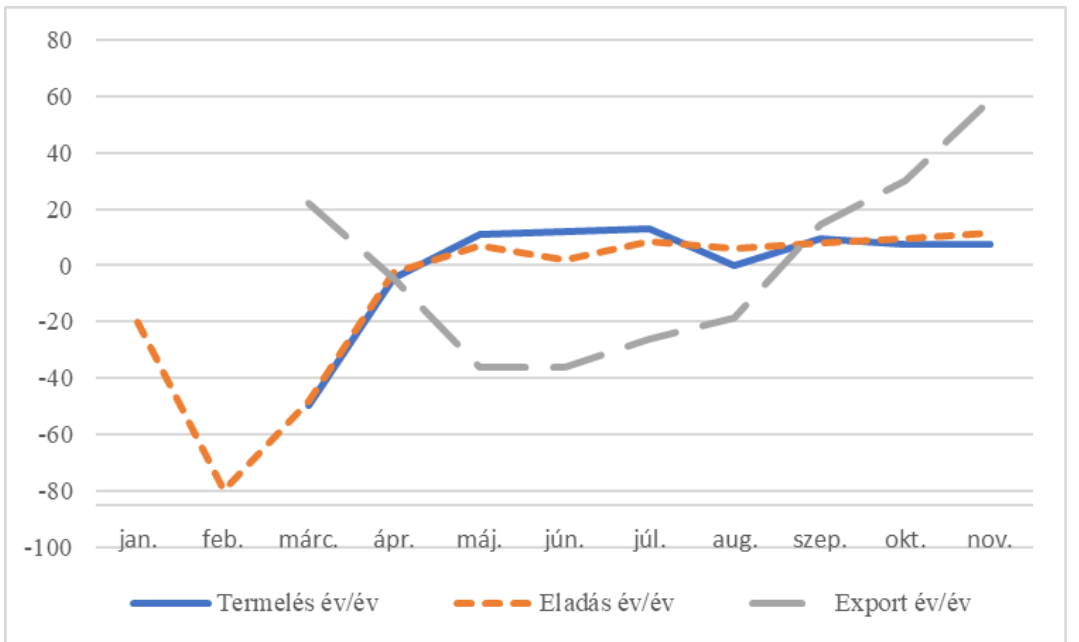

Forrás: China Association of Automoblie Manufacturers, carsalesbase.com, europe.autonews.com, saját szerkesztés 
A járvány okozta krízis az iparban és azon belül a jármüiparban Európában és a magyar gazdaságban is átmenetinek bizonyult. A hazai feldolgozóipar viszonylag hamar erőre kapott, szeptemberben már az előző év azonos hónapjának szintjét meghaladta a volumen. Hasonlóan alakult a jármügyártás alág exportja is, míg a termelés és értékesítés volumene már augusztusban magasabb volt az egy évvel korábbinál (lásd a 3. ábrát). A foglalkoztatási adatok is hasonlóan alakultak a feldolgozóipar egészében és a jármügyártásban. Az alági foglalkoztatás volumenindexe az első három negyedévben rendre 176 ezer, 166 ezer és 173 ezer fö körül alakult, azaz a válság hatására végeredményben csökkent a foglalkoztatás, de a dolgozókat a vállalkozások igyekeztek megtartani. A transznacionális nagyvállalatok a válságban meglehetősen robusztusnak bizonyultak. A krízis sokkhatása felhasználói oldalról is fokozatosan csökkent, bár a lakosság a bizonytalan jövedelmi kilátások miatt halaszthatta a tartós fogyasztási cikkek, így a személygépkocsik vásárlását.

3. ábra: A hazai jármügyártás (CL alág) termelésének, értékesítésének és exportjának volumenindexei (év/év, \%)*

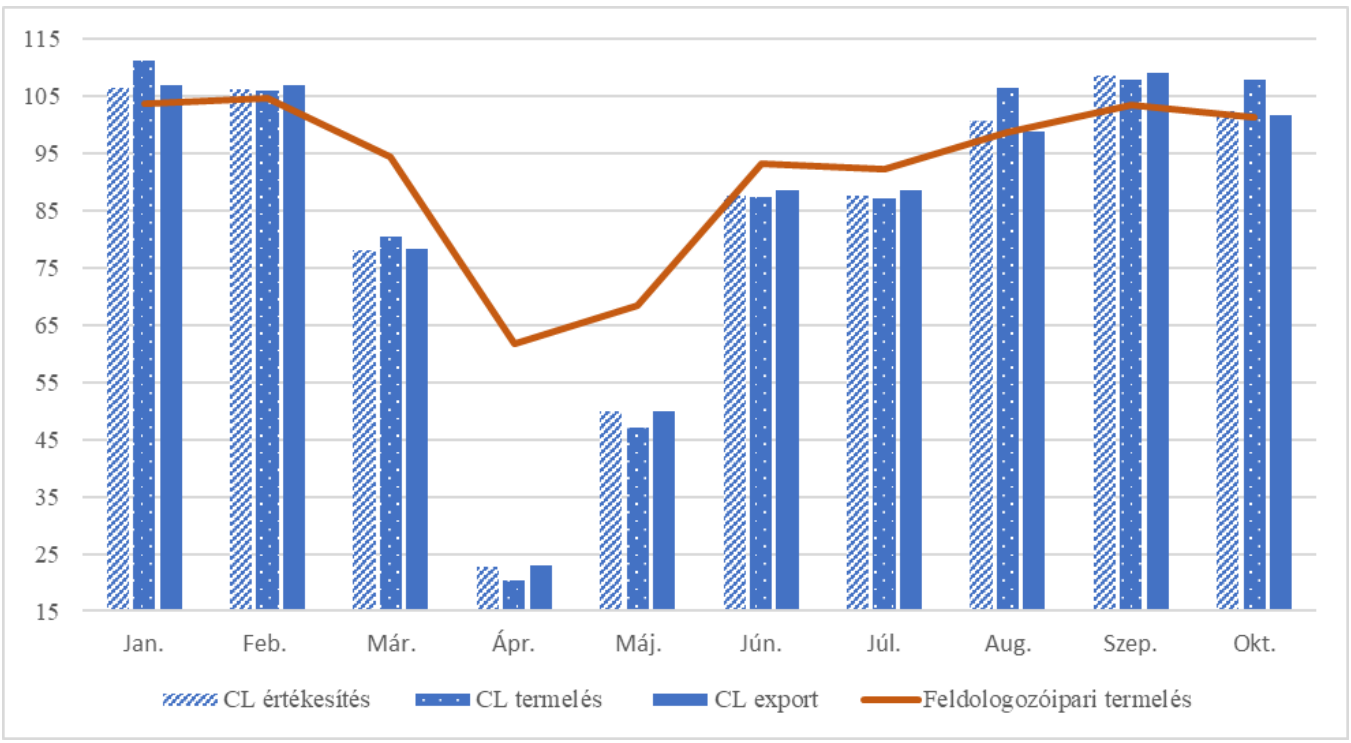

*A legalább 5 föt foglalkoztató vállalatok Forrás: KSH STADAT, saját szerkesztés

Az Európai Unióra vonatkozóan a válság hatását és lefutását jól mutató havi adatok egyelőre a regisztrált személygépkocsik számára vonatkozóan ismertek [EAMA 2020]. Bár már az első két hónapban is érezhető, $7 \%$ körüli volt az előző év azonos időszakában mért értékhez képest megfigyelt csökkenés, az index ennél a mutatónál is márciusban zuhant 45\%-kal, majd a következö hónapban érte el a mélypontot, amikor az éves csökkenés mértéke a 76\%-ot is meghaladta. A kilábalás folyamata ugyan 2020 augusztusában némileg megtört, de szeptemberben a regisztrált személygépkocsik száma már némileg meghaladta az egy évvel korábbi értéket. Az első tíz hónapra számított indexek a nagy nyugat- és dél-európai autógyártó nemzetgazdaságok (Németország, Franciaország, Olaszország, Spanyolország) esetében 25-40\% között alakultak. A tíz havi termelési indexek is hasonló csökkenéseket mutattak. A legnagyobb zuhanást a francia autógyártás szenvedte el, ahol a személygépkocsik termelése az előző év azonos időszakához képest megfeleződött.

Az Unión kívüli régiókban is jelentős visszaeséseket szenvedett el a személygépkocsi gyártás. Az USAban a csökkenés nagyjából megfelelt az európai átlagnak, míg Dél-Amerikában, és a Kínán és Dél-Koreán kívüli távol-keleti országokban a visszaesések tipikusan 30\% felett alakultak. 
Az unió személygépkocsi exportjára is csak a tízhavi indexek ismeretesek egyelőre. Némileg meglepő módon a Dél-Koreába irányuló kivitel közel 20\% növekedést tudott produkálni, miközben a többi exportpiacon jelentős csökkenést lehetett tapasztalni. Ezen belül a Kínába irányuló uniós személygépkocsi export relatíve kisebb mértékben, 13\% körül csökkent, ami körülbelül harmada az USA-ba, és fele a Japánba irányuló kivitel visszaesésének.

A havi adatok mindenesetre arra utalnak, hogy az autógyártásban a járvány okozta krízis átmeneti volt, a nagy autógyárak képesek voltak átvészelni a válságot. ${ }^{4} 2021$ januárjának második felében azonban elsősorban egyes félvezető komponensek beszállítása világszerte akadozni kezdett, amely miatt a hazai kecskeméti Mercedes gyárnak is átmenetileg le kellett állnia, a győri Audi pedig átmenetileg egy műszakra tért át a beszállítói problémák miatt. A világszerte jelentkező probléma fő oka vélhetően az volt, hogy a chipgyártók egy része átállt a szórakoztatóelektronikai alkatrészek gyártására. Várakozásaink szerint azonban ezek a problémák átmenetiek lesznek. Fontosabbak az esetleges hosszabb távú strukturális változások. Bod és szerzőtársai [2020] szerint a válság utóhatásaként várható a globális értékláncok átalakulása. Ez részben az értékláncok rövidülését, a termelési láncolatok egyszerübbé válását eredményezheti a jövőben, aminek a közép-európai régió akár a nyertese is lehet. Vesztese lehet azonban Kína, részben a merev szabályozási környezet miatt, részben pedig a világjárványok kialakulásával kapcsolatos kockázatok miatt. Fontos momentum azonban, hogy 2020 decemberében az Európai Unió és Kína átfogó kereskedelmi megállapodást kötött (Comprehensive Agreement on Investment), amely az első lépést jelenheti egy szabadkereskedelmi megállapodás felé, és jelentős előrelépést jelentett néhány ágazat, így például az elektromos autógyártás területén, ahol javultak az európai befektetők kínai piachoz jutásának feltételei. Az egyik kritikus szabályozási könnyítés, hogy a befektetőknek ezekben az ágazatokban nem kell feltétlenül vegyes vállalkozásokat létrehozni Kínában. A megállapodás kezdeményezésében vélhetően kiemelt szerepe volt a német autógyártók lobbijának.

Az autógyártás jövőjét tehát nem annyira a vélhetően 2021 folyamán végleg lecsengő járvány fogja meghatározni, inkább azok a tényezők, amelyekkel már a pandémia elött is számolni kellett. Az egyik a szükségszerü modellváltás, az elektromos meghajtású modellek terjedése, illetve túlsúlyba kerülése. Az elektromos autók gyártásának térnyerése várhatóan negatív hatással lesz az ágazati foglalkoztatásra. A foglalkoztatottság leginkább a hagyományosénál kevesebb alkatrészből álló motorból és az energiáját továbbító alkatrészekből álló úgynevezett hajtáslánc területén csökkenhet, de a tervezés, fejlesztés és az adminisztráció területén is csökkenhet a munkaerőigény. Kedvező változást eredményezhet ugyanakkor, hogy nőhet a magas szakképzettséggel rendelkezők iránti kereslet (mérnökök, szoftverfejlesztők), akik vagy fejlesztési tevékenységekben vesznek részt, vagy legalábbis képesek lesznek új technológiák adaptálására és azok müködtetésére. Természetesen a kvalifikált hazai szakembereknek a fejlesztési tevékenységekben kellene minél nagyobb súlyt képviselniük, például az önvezető járművek területén. ${ }^{5}$

A másik hatás az automatizáció és a digitalizáció további fejlődése az ágazatban, ami a humán munkahelyek további csökkenése irányában hat [lásd például Losonci et al., 2019].

\footnotetext{
${ }^{4}$ Érdekes adalék ehhez a hazai Audi vezérigazgatójának 2021 elején tett nyilatkozata, amely szerint az autógyárak és beszállítóik képesek túlélni a járvány okozta válságot, a kormányoknak válságkezelés címén inkább a sebezhetőbb ágazatokat, például a vendéglátóipart, a rendezvényszervezést kellene támogatniuk.

${ }^{5}$ Erre úttörő példa a ZalaZone Kutatási és Technológiai Központ létrejötte.
} 


\section{Hosszabb távú versenyképességi hatások és a hazai foglalkoztatási következmények}

Az autóipar hosszabb távú lehetőségeit nagyban meghatározzák a jelenleg is zajló nemzetközi kereskedelmi megállapodások. A korábbi évek protekcionista lépései után arra lehet számítani, hogy az új megállapodások egyfajta korrekciót jelentenek majd, 5-10 éven belül a jármükereskedelem liberalizáltabbá válhat a jelenleginél. Ennek következtében jelentősen átalakulhatnak az iparágban megszokott értékláncok. Ez viszont nem feltétlenül jelenti azok rövidülését, bár ezt gyakran hallhattuk a koronavírus okozta gazdasági válság kapcsán.

Az autóipari cégek kapcsolatrendszerének átalakulására figyelmeztet a World Economic Forum [2020] jelentése is, amely elsősorban a vállalati felmérésekre helyezte a hangsúlyt. A jelentés szerint a cégek többsége tisztában van azzal, hogy öt éven belül megváltozhatnak a szállítási láncok, és jellemzően arra számítanak, hogy növekedni fog az értékláncban részt vevő üzleti partnerek száma. Ezt azzal magyarázzák, hogy erősödni fog a feladat-specializáció, vagyis egy-egy vállalat a gyártási folyamat, illetve szolgáltatások egyre szükebb területére fog koncentrálni.

A munkaerőpiaci tendenciák kapcsán a cégek általában egyszerre említik a tevékenységükhöz szükséges munkaerő várható csökkenését és növekedését, csak éppen különböző területeken. A változások szaldója nem egyértelmü, de az biztos, hogy pár éven belül érdemben megváltozik majd az alkalmazottak képzettségének szerkezete. Biztosnak tünik, hogy a digitális képességek növelése szinte minden területen elengedhetetlen lesz, és egyre rugalmasabb munkavállalókra lesz igény. Ebből következően a vállalati menedzserek várakozásai szerint a következő 5 évben a munkavállalók nagyjából 50\%-a lesz kénytelen olyan képzéseken részt venni, amelyeknek köszönhetően új képességekre tehetnek szert, és az esetek többségében ez az alapvető képességeket is érinti majd.

A cégek várakozásai szerint az autóipari alkalmazottak körében az olyan típusú készségek válnak egyre fontosabbá, mint például az analitikus gondolkodás, a problémamegoldás, az innovatív szemlélet, kritikus gondolkodás, a rugalmasság, a stressztűrő képesség, az aktív tanulás képessége vagy a kreativitás. Így az autóiparban egyre több adatelemzőre, mesterséges intelligencia szakértőre, üzleti fejlesztőre, digitális átalakulás szakértőre, szervezetfejlesztőre, robotikai mérnökre, stratégiai tanácsadóra, adatbázis- és hálózati szakértőre, valamint környezetvédelmi szakértőre lesz szükség. Ezeken a területeken tehát a foglalkoztatás növekedése várható, és az is egyértelmü, hogy ezek a tevékenységek az átlagosnál jobban képzett szakembereket igényelnek.

Ezzel szemben az olyan területek, mint a számvitel, adminisztráció, auditálás, pénzügyi müveletek és azok elszámolása, hagyományos értékesítés, fizikai összeszerelés, illetve gyári munka egyre kevesebb munkaerőt igényelnek a jövőben. A jelentés szerint ezek a tevékenységek ugyanis részben vagy egészben kiválthatók a robotizáció és az automatizálás további terjedésével. A World Economic Forum [2020] szerzői felhívják a figyelmet arra, hogy ezek a leépülőben lévő feladatok jellemzően monoton és kevéssé kreatív munkafolyamatok voltak, amelyeket számos esetben kevéssé képzett vagy képzetlen munkavállalók is el tudtak látni.

Az autóiparban foglalkoztatott munkaerő szerkezeti átalakulása várhatóan együtt jár majd azzal, hogy tovább növekszik a különbség a képzettek és a képzetlenek jövedelme között. Ez számos esetben komoly érdeksérelmeket okozhat, amire cégvezetőknek fel kell készülniük. Ennek egyre fontosabb eszköze lehet a munkahelyi átképzések, továbbképzések folyamatosan bővülő kínálata. Ezen a területen egyfajta szemléletváltásra van szükség: sok vállalat eddig amolyan szükséges rosszként tekintett ezekre a programokra, a következő évtizedben azonban fel kell ismerni, hogy folyamatos humántőke-beruházások nélkül a cégek nem őrizhetik meg versenyképességüket. A vállalati felmérések alapján kijelenthető, hogy 
egyre több szereplő fogadja el ezt a helyzetet, és a következő 5 évben egyre növekvő összeget szánnak erre a területre.

A szemléletváltás másik terepe a munkahelyi well-being elfogadása és növekvő szerepe lehet. A korábban a technológiai cégekre jellemző látásmód várhatóan az autóiparban is gyorsan meghonosodhat. Ennek lényege, hogy a vállalatok felismerik, hogy a munkához kapcsolódó jóllét növelése jelentősen javíthatja a cég termelékenységét. A kellemes munkakörnyezet, a rugalmas időbeosztás, a széleskörüen igénybe vehető munkahelyi szolgáltatások gyorsan megtérülő befektetést jelentenek a munkáltató számára. Sőt, ahogy nő a munkavállalók átlagos képzettsége, úgy emelkednek az elvárások ezen a területen is. Egyre gyakrabban hallani cégvezetőktől, hogy a megfelelő munkaerő megtalálásához elengedhetetlen a munkahelyi well-being megfelelő szintje.

Jelentős változás várható a digitális munka és a helyhez nem kötött munkavégzés területén is. A koronavírus-válság értelemszerüen nagy lökést adott ennek a folyamatnak, de a vállalati menedzserek szerint nem egyszeri fellendülésről, hanem tartós tendenciáról van szó. Az autóipar annyiban speciális helyzetben van, hogy mindig lesznek olyan munkafolyamatok, amelyek esetében nem valósítható meg a távmunka, de a cégek szintjén jelentősen nőhet az aránya.

Az autóipari cégek jelentős arányban számoltak be arról, hogy középtávon új technológiák adaptálását tervezik. Ezek közül a leggyakrabban a kiberbiztonságot, a big data elemzéseket, az IOT technológiákat (internet of things) említették. Számos vállalat tervez IT beruházásokat, és közülük feltűnően sokan említették, hogy a jövőben szeretnének felhőalapú szolgáltatásokat igénybe venni. Az ilyen típusú befektetések azért is nélkülözhetetlenek, mert az autóiparban is folyamatosan nő az elektronikus értékesítés és a digitális kereskedelem aránya. Mindez együtt jár a hagyományos marketingstratégiák teljes újratervezésével, aminek már említettük a munkaerőpiaci következményeit.

\section{A munkahely rugalmasságának változása a digitalizációs folyamatban}

A digitalizáció és a technológiai fejlődés erősíti mind a munkahelyek, mind a munkaerő képességeinek folyamatos fejlesztésére nehezedő nyomást is. Fontos előre látnunk, hogy a vállalatok milyen típusú készségeket és kompetenciákat helyeznek előtérbe, amikor ezeket megvalósítják. Az új digitális technológiák egyrészt kiválthatják a rutinszerü, esetleg az egészségre is káros gyakorlati feladatokat, másrészt viszont hozzájárulhatnak az új típusú képességek és kompetenciákkal rendelkező munkavállaó termelékenységének javulásához.

A jövő nemzedékei, a Z és az Alfa generáció magasan képzett munkavállalói számára kiemelten fontossá vált az anyagi elismerés mellett a munkavégzés rugalmassága (időbeli és térbeli értelemben) is [Benke et al., 2020]. Egy, a magyar egyetemisták körében végzett, a jövőbeni munkahelyükkel kapcsolatos feltérképezést célzó kérdőíves felmérés eredményei alapján [Cserháti et al., 2020] a magyar fiatalok számára is a munkahely rugalmassága vált az egyik legfontosabb tényezővé a munkahelyválasztásuk során: a munka mellett önmegvalósítási, magánéleti céljaikat is el szeretnék érni. Ezért érdemes megvizsgálni, hogy a digitalizáció a foglalkoztatás mennyiségére gyakorolt hatásán túl milyen átalakulásokat eredményezhet a munkavégzés jellegében.

A digitalizáció három területe és várható hatása a munkavégzés rugalmasságára

A digitalizációnak a képzett munkaerő-keresletre, valamint annak rugalmas jellegére gyakorolt hatásának megvilágításához Rolandsson et al. [2020] alapján a digitalizáció három különböző formáját különböztetjük meg, amelyek mindegyikének különféle következményei vannak a készségek átalakítására. 
Áttekintjük, hogy a digitalizáció milyen változásokat indukálhat a termelésben, az adminisztrációban és a kommunikációban.

A termelés digitalizálása (automatizáció, robotizáció) átalakítja a munkavállalók által elvégzendő munkákat, korszerüsítik a termelési folyamatokat, amelyek bizonyos készségeket és munkahelyeket elavulttá tesznek [Frey és Osborne, 2017], a munkájukat megőrzőknek a huszonegyedik századi készségek (együttmüködés, kritikus gondolkozás, problémamegoldó képesség, kreativitás stb.) szélesebb körének birtokában kell lenniük. Az autóiparban ez a folyamat megállíthatatlan, a flexibilis munkavégzés aránya a termelési folyamatokban korlátozottabb, de a digitális ellenőrzési területeken a szerepe növekedhet.

Az adminisztráció digitalizálása során a szervezetek kiterjedten használják a digitális technológiákban rejlő lehetőségeket az adatok nyilvántartásában, tárolásában és kezelésében, a folyamatok monitorozásában. Ezen a területen az autóiparban is jelentősebb szerepe lehet a távmunkának, a rugalmasabb munkavégzési formáknak, de ehhez a digitális kompetenciák és kognitív készségek folyamatos fejlesztésére van szükség. Ellenkező esetben ezek a területek könnyedén kiszervezhetők olcsóbb munkaerőköltséggel bíró régiókba, országokba. Ezen a területen jelentős változások várhatók a hazai autóiparban is, a tevékenység jellegéből adódóan a rugalmasabb munkavégzési formák további terjedése várható.

A kommunikáció digitalizálása olyan hálózati technológiák felhasználására támaszkodik, amelyek segítik a termékfejlesztést, a csapatmunkát, az innovációt, és lehetőséget biztosítanak személyre szabott szolgáltatások kifejlesztésére is. A digitális kommunikációs platformok elterjedése révén viszont mind a munkaadók, mind a munkavállók rugalmasabban dönthetnek az adott pozíció betöltéséről. Az autóiparban is valószínüsítjük a kommunikációhoz kapcsolódó tevékenységek rugalmasabbá válását.

\section{Az autóipar rugalmassági potenciáljának becslése}

A várható folyamatok elméleti áttekintését követően számszerü becslést készítünk arra vonatkozóan, hogy a hazai autóipar milyen mértékben válhat rugalmassá a digitalizációs folyamat során, azaz a tevékenységek hány százaléka lesz majd elvégezhető rugalmas formában, legalább részben helyfüggetlen módon.

A modellezési folyamat lépései a következők voltak.

a) Kialakítottuk az adatbázisunkat: az EU-SILC ${ }^{6}$ 2018. évi mikroszintü, egyéni adatbázisát használtuk. A személyi állomány mintegy 13 ezer megfigyeléséből azokat a rekordokat vettük figyelembe, ahol mind a tevékenységtípus (ISCO-2008), mind pedig a munkahely ágazati besorolása (NACE rev.2) kitöltött volt.

b) Felhasználtuk Dingel és Neiman [2020] eredményeit, akik kutatásukban az USA-ban használt mintegy 1330 tevékenységtípusra (SOC rendszer) meghatározták, hogy az adott tevékenységtípus elvileg elvégezhető-e rugalmasan, távmunkában vagy nem (1/0).

c) A US Bureau of Labor Statistics által kidolgozott átmenet mátrix segítségével áttértünk az európai tevékenység besorolásokra (SOC-ISCO). A teljes konzisztencia érdekében néhány esetben saját becsléseket is végeztünk az egyik vagy másik nomenklatúrából hiányzó tevékenység jellegének meghatározására.

d) A teljes átmenetmátrix segítségével elvégeztük az átkódolást, azaz minden ISCO-2008 kód szerinti tevékenységre kiszámoltuk az átlagos ,potenciális rugalmassági arányt”, azaz az adott tevékenységen belül azt a maximális részarányt, ami elvileg rugalmas formában, helyfüggetlen módon is elvégezhető. Ezzel a rugalmassági potenciál változóval (az ISCO kód által determinált 
egyéni értékkel) az adatbázis minden egyes rekordját kiegészítettük, és a foglalkozás jellege szerint elemeztük a rugalmassági potenciált.

e) Az egyedi potenciális rugalmasságokat ágazatonként aggregáltuk, természetesen figyelembe véve az adott megfigyelési egységnek (a mintában szereplő foglakoztatott személynek) az adatbázisban szereplö, a KSH által meghatározott sokasági súlyát is.

f) Értékeltük a jármügyártás és a nemzetgazdasági rugalmassági potenciálját.

\subsection{Eredmények a foglalkozás típusa szerint}

Az a-d. pontok szerint eljárva megbecsültük a magyarországi rugalmassági potenciált a foglakozások jellege (ISCO-2008 2 számjegy) szerint (2. táblázat). Látható, hogy a magasabb képzett munkaerőt igénylő foglalkozástípusok magasabb rugalmassági potenciállal jellemezhetők. A rugalmassági potenciál a 2018. évi foglalkoztatási szerkezetet tükrözi, a COVID-19 járvány hatására ezek az értékek tovább emelkedhettek.

\section{2. Ágazati eredmények}

Az egyedi szintü mutatókat ágazatonként is aggregálhatjuk és elemezhetjük. A 3. táblázat alapján egyértelmü, hogy a leginkább digitalizálható, és így rugalmasabb keretek között is végezhetö tevékenységek az informatikához, a tudományos kutatói tevékenységekhez, a reklám- és pénzügyi területekhez kötődnek. Legkevésbé azokban az ágazatokban alacsony a rugalmassági potenciál, ahol a döntően elemi tevékenységek megkövetelik a fizikai jelenlétet (fafeldolgozás, textilipar, hulladékkezelés). A fegyveres erőknél teljeskörü a jelenléti munkavégzés. Az autóipar rugalmassági helyzetét elemezve látható, hogy az ágazatok alsó harmadában helyezkedik el, és a becsült 11,7\%-os rugalmassági potenciál azt jelenti, hogy a 2018. évi foglakoztatási szerkezet szerint a tevékenységeknek csak valamivel több mint 10\%-a minősült „rugalmasítható” tevékenységnek, ami a nemzetgazdasági átlagnak $(28,6 \%)$ csak alig valamivel több mint 40\%-a.

Az eredmények értékelésénél két tényezőt kell figyelembe vennünk. Egyrészt azt, hogy egy olyan hagyományosan jelenléti típusú feldolgozóipari ágazatban, mint a jármügyártás, véleményünk szerint ez az arány is magasabb az általánosan vártnál, másrészt azt, hogy a 2018. évi tevékenységszerkezet már 2021 elejéig is jelentősen módosulhatott, a válságot követően pedig további digitalizációs forradalom várható ezen a területen. A kutatási eredmények szerint ez a folyamat várhatóan a magasan képzett munkaerő részarányát növelheti ebben a szektorban, ami felveti a rugalmasság további térnyerését még ebben a hagyományosan jelenléti szektorban is.

\section{5. Összefoglalás}

A hazai jármügyártás a nemzetközi tendenciáknak megfelelően a koronavírus okozta krízis után viszonylag hamar visszatért a válság előtti szinthez, a nagy autógyárak robusztusnak bizonyultak, bár 2021 elején a beszállítási problémák miatt világszerte újból fennakadások keletkeztek az értékláncokban. A vélhetően rövid távon megoldódó problémákhoz képest az ágazat jövőjét az értékláncok esetleges tartós átalakulása, rövidülése, és a termelési struktúraváltás - elsősorban az elektromos meghajtású jármüvek terjedése határozza meg. Utóbbi az automatizáció és digitalizáció hatásaihoz hasonlóan az ágazati foglalkoztatottság csökkenésének irányába hat. Fontos kérdés ugyanakkor, hogy a foglalkoztatás rugalmas formái milyen mértékben tudnak ebben az alapvetően helyhez kötöttnek tekinthető ágazatban eltrejedni. A tanulmányban modellszámítással becsültük meg, hogy a hazai jármügyártásban a tevékenységek hány százaléka lesz majd 
elvégezhető rugalmas formában, legalább részben helyfüggetlen módon. Ehhez az EU SILC 2018. évi adatbázisát használtuk, illetve Dingel és Neiman [2020] eredményeiből indultunk ki, hogy ágazatailag is meghatározzuk a rugalmas foglalkoztatás várható arányait. Eredményeink szerint ez az arány a közúti járművek gyártásának átlagában elérheti a 12\%-ot, amely kevesebb, mint a fele a teljes nemzetgazdaságra számolt aránynak. Ez a potenciál tehát ebben az ágazatban is jelentős, de ágazati összehasonlításban mérsékeltnek tekinthető.

2. táblázat: Rugalmassági potenciál Magyarországon a foglalkozás jellege szerint

\begin{tabular}{|c|c|c|c|c|c|}
\hline $\begin{array}{l}\text { ISCO } \\
\text { kód }\end{array}$ & A foglalkozás megnevezése & $\begin{array}{l}\text { Rugal- } \\
\text { massági } \\
\text { potenciál }\end{array}$ & $\begin{array}{c}\text { ISCO } \\
\text { kód }\end{array}$ & A foglalkozás megnevezése & $\begin{array}{l}\text { Rugal- } \\
\text { massági } \\
\text { potenciál }\end{array}$ \\
\hline 1 & Vezetök & & 6 & Szakképesített mezőgazdasági és halás zati foglalkozások & \\
\hline 11 & $\begin{array}{l}\text { Vezérigazgatók, igazgatási vezetők és } \\
\text { törvényhozók }\end{array}$ & $90.9 \%$ & 61 & Piacra termelő szakképesített mezőgazdasági foglalkozások & $5.0 \%$ \\
\hline 12 & Igazgatási és gazdasági vezetők & $90.0 \%$ & 62 & $\begin{array}{l}\text { Piacra termelő szakképesített erdészeti, halászati és vadászati } \\
\text { foglalkozások }\end{array}$ & $0.0 \%$ \\
\hline 13 & Termelési vezetők, szakszolgálatok vezetői & $48.1 \%$ & 63 & Saját szükségletre termelő gazdák, halászok, vadászok és gyűjtögetők & $0.0 \%$ \\
\hline 14 & $\begin{array}{l}\text { Vendéglátó-ipari, kis- és nagykereskedelmi } \\
\text { szolgáltatások vezetöi }\end{array}$ & $50.0 \%$ & & & \\
\hline 2 & $\begin{array}{l}\text { Felsőfokú képzettséget igénylő } \\
\text { foglalkozás ok }\end{array}$ & & 7 & Szakképzettséget igénylő ipari foglalkozások & \\
\hline 21 & Természettudományi és müszaki foglalkozások & $61.5 \%$ & 71 & Építőipari és hasonló foglalkozások, kivéve a villanyszerelöket & $2.6 \%$ \\
\hline 22 & Egészségügyi foglalkozások & $10.9 \%$ & 72 & Fém-, gépipari és hasonló foglalkozások & $0.0 \%$ \\
\hline 23 & Oktatási foglalkozások & $91.9 \%$ & 73 & Kézmüipari és nyomdaipari foglalkozások & $28.0 \%$ \\
\hline 24 & Üzleti és igazgatási foglalkozások & $92.6 \%$ & 74 & Erős- és gyengeáramú villamos ipari szerelők & $0.0 \%$ \\
\hline 25 & $\begin{array}{l}\text { Információs és kommunikációs technológiai } \\
\text { foglalkozások }\end{array}$ & $100.0 \%$ & 75 & Élelmiszer-, fa-, textilipari és hasonló vegyesipari foglalkozások & $7.5 \%$ \\
\hline 26 & Jogi, szociális és kulturális foglalkozások & $69.4 \%$ & & & \\
\hline 3 & Technikusok és hasonló foglalkozások & & 8 & Gépkezelők és összesze re lők, jármüvezetők & \\
\hline 31 & Természettudományi és műszaki foglalkozások & $16.3 \%$ & 81 & Helyhez kötött berendezések és gépek kezelői & $0.0 \%$ \\
\hline 32 & Egészségügyi foglalkozások & $4.0 \%$ & 82 & Összeszerelök & $0.0 \%$ \\
\hline 33 & Üzleti és igazgatási foglalkozások & $70.0 \%$ & 83 & Jármüvezetők és mobilgépkezelök & $0.0 \%$ \\
\hline 34 & $\begin{array}{l}\text { Jogi, szociális, kulturális és hasonló területeken } \\
\text { dolgozókat segitő foglalkozások }\end{array}$ & $43.8 \%$ & & & \\
\hline 35 & $\begin{array}{l}\text { Információs és kommunikációs technológiai } \\
\text { technikusok }\end{array}$ & $91.7 \%$ & & & \\
\hline 4 & Irodai foglalkozások & & 9 & Egyszerü fgolallkozások & \\
\hline 41 & $\begin{array}{l}\text { Általános irodai foglalkozások, gépírók és } \\
\text { adatrögzítők }\end{array}$ & $100.0 \%$ & 91 & Takarítók és segítők & $0.0 \%$ \\
\hline 42 & Ügyfélforgalmi szolgáltatási foglalkozások & $34.5 \%$ & 92 & $\begin{array}{l}\text { Képesítést nem igénylő mezőgazdasági, erdészeti és halászati } \\
\text { foglalkozások }\end{array}$ & $0.0 \%$ \\
\hline 43 & Számviteli és anyagnyilvántartók & $47.1 \%$ & 93 & $\begin{array}{l}\text { Képesítést nem igénylő bányászati, építőipari, ipari és közlekedési } \\
\text { foglalkozások }\end{array}$ & $6.5 \%$ \\
\hline \multirow[t]{3}{*}{44} & Egyéb irodai kisegítő foglalkozások & $70.6 \%$ & 94 & Képesítést nem igénylő vendéglátó-ipari foglalkozások & $0.0 \%$ \\
\hline & & & 95 & Utcai és hasonló árusok, szolgáltatók & $0.0 \%$ \\
\hline & & & 96 & Hulladékgazdálkodók és egyéb képesítést nem igénylö foglalkozások & $16.7 \%$ \\
\hline 5 & Szolgáltatási és éfrtékesítési fgolalkozások & & $\mathbf{0}$ & Fegyveres erôk & \\
\hline 51 & Személyi szolgáltatásokat nyújtó foglalkozások & $12.8 \%$ & 1 & Fegyveres erők tisztjei & $0.0 \%$ \\
\hline 52 & Értékesítési foglalkozások & $19.0 \%$ & 2 & Fegyveres erők tiszthelyettesei & $0.0 \%$ \\
\hline 53 & Személygondozási foglalkozások & $17.6 \%$ & 3 & Fegyveres erők egyéb rangú állománya & $0.0 \%$ \\
\hline 54 & Védelmi foglalkozások & $5.0 \%$ & & & \\
\hline
\end{tabular}

Forrás: EU SILC 2018, saját számítás 
3. táblázat: Rugalmassági potenciál Magyarországon ágazatonként

\begin{tabular}{|c|c|c|c|}
\hline Sorszám & $\begin{array}{l}\text { TEÁOR'08 } \\
\text { kód }\end{array}$ & Ágazat megnevezése & $\begin{array}{c}\text { Rugalmassági } \\
\text { potenciál }\end{array}$ \\
\hline 1. & 62 & Információ-technológiai szolgáltatás & $93.0 \%$ \\
\hline 2. & 63 & Információs szolgáltatás & $90.9 \%$ \\
\hline 3. & 72 & Tudományos kutatás, fejlesztés & $84.3 \%$ \\
\hline 4. & 73 & Reklám, piackutatás & $77.7 \%$ \\
\hline 5. & 64 & $\begin{array}{l}\text { Pénzügyi közvetítés, kivéve: } \\
\text { biztosítási, nyugdíjpénztári } \\
\text { tevékenység }\end{array}$ & $73.6 \%$ \\
\hline 68. & 29 & Közúti jármü gyártása & $11.7 \%$ \\
\hline 82. & 16 & $\begin{array}{l}\text { Fafeldolgozás (kivéve: bútor), } \\
\text { fonottáru gyártása }\end{array}$ & $4.8 \%$ \\
\hline 83. & 97 & $\begin{array}{l}\text { Háztartási alkalmazottat } \\
\text { foglalkoztató magánháztartás }\end{array}$ & $2.8 \%$ \\
\hline 84. & 39 & $\begin{array}{l}\text { Szennyeződésmentesítés, egyéb } \\
\text { hulladékkezelés }\end{array}$ & $1.3 \%$ \\
\hline 85. & 13 & Textília gyártása & $1.3 \%$ \\
\hline 86. & 3 & Fegyveres erők foglalkozásai & $0.0 \%$ \\
\hline \multicolumn{3}{|c|}{ Nemzetgazdaság összesen } & $28.6 \%$ \\
\hline
\end{tabular}

Forrás: EU-SILC 2018, saját számítás

\section{Felhasznált irodalom:}

Benke, D., Cserháti, I. és Takács, T. (2020): „A távmunka perspektívái Magyarországon” in: Cserháti, I. (szerk.): Munkapiaci trendek - demográfiai és jóléti kihivások, 187-204., Typotex Kiadó.

Bod, P. Á., Cserháti, I. és Takács, T. (2020): „Makrogazdasági, államháztartási helyzetkép és kitekintés 2020-2022re" in: Halm, T. szerk: Makrogazdaság, államháztartás koronavirus-járvány idején - A Költségvetési Tanács részére készült elemzések, 2020, 70-79., Magyar Közgazdasági Társaság.

Cserháti, I., Keresztély, T. és Madari, Z. (2020): „A jövő munkahelyével kapcsolatos elvárások/várakozások alakulása” in: Cserháti, I. (szerk.): Munkapiaci trendek - demográfiai és jóléti kihívások, 281-297., Typotex Kiadó.

Dingel, J. I. és Neiman, B. (2020): How many jobs can be done at home? NBER Working Paper No. 26948, April 2020.

EAMA (2020): Economic and market report - EU Automotive industry, first three quarters of 2020. European Automotive Manufacturers Association.

https://www.acea.be/uploads/statistic_documents/Economic_and_Market_Report-First_three_quarters_2020.pdf letöltve: 2021.01.24 
Frey, C. B. és Osborne, M. A. (2017): „The future of employment: How susceptible are jobs to computerisation?” Technological Forecasting an Social Change, 114: 254-280.

KSH (2020): Helyzetkép az iparról, 2019, Központi Statisztikai Hivatal

https://www.ksh.hu/docs/hun/xftp/idoszaki/jelipar/2019/index.html Letöltve: 2021.01.24.

Losonci, D., Takács, O. és Demeter, K. (2019): „Az ipar 4.0 hatásainak nyomában - a magyarországi járműipar elemzése" Közgazdasági Szemle, LXVI. évf., 185-218.

Rechnitzer, J., Hausmann, R. és Tóth, T. (2017): „A magyar autóipar helyzete nemzetközi tükörben” Hitelintézeti Szemle, 16(1): 119-142.

Rolandsson, B., Alasoini, T., Dølvik, J. E., Hedenus, A., Larsen, T. P., Ilsøe, A., Røed-Steen, J. és Hjelm E. (2020): "Nordic manufacturing in transition - Perspectives on digitalization and skill requirements" in: Rolandsson, B. (szerk.): Digital transformations of traditional work in the Nordic Countries

https://pub.norden.org/temanord2020-540/\#44301 Letöltve: 2021.01.24.

World Economic Forum (2020): The Future of Jobs Report 2020

https://www.weforum.org/reports/the-future-of-jobs-report-2020 